\title{
Front Matter: Volume 6762
}

, "Front Matter: Volume 6762," Proc. SPIE 6762, Two- and Three-Dimensional Methods for Inspection and Metrology V, 676201 (22 October 2007); doi: 10.1117/12.781776

SPIE. Event: Optics East, 2007, Boston, MA, United States 


\section{PROCEEDINGS OF SPIE}

\section{Two- and Three-Dimensional Methods for Inspection and Metrology $V$}

Peisen S. Huang

Editor

11-12 September 2007

Boston, Massachusetts, USA

Sponsored and Published by

SPIE

Volume 6762 
The papers included in this volume were part of the technical conference cited on the cover and title page. Papers were selected and subject to review by the editors and conference program committee. Some conference presentations may not be available for publication. The papers published in these proceedings reflect the work and thoughts of the authors and are published herein as submitted. The publisher is not responsible for the validity of the information or for any outcomes resulting from reliance thereon.

Please use the following format to cite material from this book:

Author(s), "Title of Paper," in Two- and Three-Dimensional Methods for Inspection and Metrology V, edited by Peisen S. Huang, Proceedings of SPIE Vol. 6762 (SPIE, Bellingham, WA, 2007) Article CID Number.

ISSN 0277-786X

ISBN 9780819469229

Published by

SPIE

P.O. Box 10, Bellingham, Washington $98227-0010$ USA

Telephone +1 3606763290 (Pacific Time) · Fax +1 3606471445

SPIE.org

Copyright (c) 2007, Society of Photo-Optical Instrumentation Engineers

Copying of material in this book for internal or personal use, or for the internal or personal use of specific clients, beyond the fair use provisions granted by the U.S. Copyright Law is authorized by SPIE subject to payment of copying fees. The Transactional Reporting Service base fee for this volume is $\$ 18.00$ per article (or portion thereof), which should be paid directly to the Copyright Clearance Center (CCC), 222 Rosewood Drive, Danvers, MA 01923. Payment may also be made electronically through CCC Online at copyright.com. Other copying for republication, resale, advertising or promotion, or any form of systematic or multiple reproduction of any material in this book is prohibited except with permission in writing from the publisher. The CCC fee code is $0277-786 \mathrm{X} / 07 / \$ 18.00$.

Printed in the United States of America.

Publication of record for individual papers is online in the SPIE Digital Library.

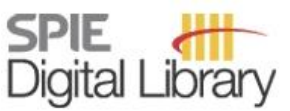

SPIEDigitalLibrary.org

Paper Numbering: Proceedings of SPIE follow an e-First publication model, with papers published first online and then in print and on CD-ROM. Papers are published as they are submitted and meet publication criteria. A unique, consistent, permanent citation identifier (CID) number is assigned to each article at the time of the first publication. Utilization of CIDs allows articles to be fully citable as soon they are published online, and connects the same identifier to all online, print, and electronic versions of the publication. SPIE uses a six-digit CID article numbering system in which:

- The first four digits correspond to the SPIE volume number.

- The last two digits indicate publication order within the volume using a Base 36 numbering system employing both numerals and letters. These two-number sets start with 00, 01, 02, 03, 04, 05, $06,07,08,09,0 \mathrm{~A}, 0 \mathrm{~B} \ldots \mathrm{OZ}$, followed by $10-1 \mathrm{Z}, 20-2 \mathrm{Z}$, etc.

The CID number appears on each page of the manuscript. The complete citation is used on the first page, and an abbreviated version on subsequent pages. Numbers in the index correspond to the last two digits of the six-digit CID number. 


\section{Contents}

$\checkmark$ Conference Committee

\section{SESSION 1 3D AND MACHINE VISION METHODS}

676202 Smooth 3D edge detection in scarfed composite surfaces [6762-01]

R. Ramamurthy, M. Navalgund, Q. HU, K. G. Harding, GE Global Research Ctr. (USA)

676203 Depth and focused image recovery from defocused images for cameras operating in macro mode [6762-02]

X. Tu, Y. Kang, M. Subbarao, State Univ. of New York at Stony Brook (USA)

676204 Absolute phase retrieval for 3D shape measurement by the Fourier transform method [6762-03]

H. Guo, P. S. Huang, Stony Brook Univ. (USA)

676205 Single image depth edges classification using a red, green, and blue light [6762-05] M. Voigt, F. Ospald, V. Ramesh, Siemens Corporate Research, Inc. (USA)

\section{SESSION 2 3D METHODS AND DATA MERGING}

676207 Multiple views merging from different cameras in fringe-projection based phase-shifting method [6762-07]

Q. Hu, K. Harding, D. Hamilton, GE Global Research Ctr. (USA); J. Flint, GE Energy (USA)

676208 The concept of virtual landmarks in 3D multi-view fringe projection [6762-08] G. Notni, P. Kühmstedt, M. Heinze, C. Munkelt, Fraunhofer Institute for Applied Optics and Precision Engineering, Jena (Germany)

676209 3D data merging using Holoimage [6762-09]

S. Zhang, S.-T. Yau, Harvard Univ. (USA)

6762 0A Improved feature descriptors for 3D surface matching [6762-10]

L. J. Skelly, MIT Lincoln Lab. (USA); S. Sclaroff, Boston Univ. (USA)

\section{SESSION 3 3D APPLICATIONS}

6762 OB Applications of a MEMS scanner to profile measurement [6762-11]

T. Yoshizawa, T. Wakayama, Saitama Medical Univ. (Japan); H. Takano, ALT Inc. (Japan)

6762 OD Development of a compact inner profile measuring instrument [6762-13]

T. Wakayama, Saitama Medical Univ. (Japan); H. Takano, ALT Inc. (Japan); T. Yoshizawa, Saitama Medical Univ. (Japan) 
6762 OE Intraoral 3D scanner [6762-14]

P. Kühmstedt, C. Bräuer-Burchardt, C. Munkelt, M. Heinze, M. Palme, I. Schmidt, Fraunhofer IOF Jena (Germany); J. Hintersehr, Hint-Els DentaCAD Systeme (Germany); G. Notni,

Fraunhofer IOF Jena (Germany)

6762 OF Hybrid interferometric structured light method for surface mapping [6762-15]

K. Harding, G. Abramovich, GE Global Research (USA)

\section{SESSION 4 SYSTEM OPTIMIZATION METHODS}

6762 OG Network-based production quality control [6762-16]

Y. Kwon, Ajou Univ. (South Korea); B. Tseng, Univ. of Texas, El Paso (USA); R. Chiou, Drexel Univ. (USA)

$6762 \mathrm{OH} \quad$ Optimized scattering compensation for time-of-flight camera [6762-17]

J. Mure-Dubois, H. Hügli, Univ. of Neuchâtel (Switzerland)

6762 Ol A ray tracing approach to inverse pattern profilometry [6762-18]

V. Putz, B. G. Zagar, Johannes Kepler Univ. (Austria)

\section{POSTER SESSION}

6762 OK Mobile shearography in applications [6762-20]

M. Kalms, BIAS-Bremer Institut of Applied Beam Technology (Germany)

Author Index 


\title{
Conference Committee
}

\author{
Symposium Chairs \\ Tuan Vo-Dinh, Duke University (USA) \\ Robert A. Lieberman, Intelligent Optical Systems, Inc. (USA) \\ Conference Chair
}

Peisen S. Huang, Stony Brook University (USA)

Program Committee

Kevin G. Harding, GE Global Research Center (USA)

Qingying Hu, GE Global Research Center (USA)

Heinz Hügli, Université de Neuchâtel (Switzerland)

Charles Joenathan, Rose-Hulman Institute of Technology (USA)

John W. V. Miller, University of Michigan (USA)

Shizhuo S. Yin, The Pennsylvania State University (USA)

Toru Yoshizawa, Saitama Medical University (Japan)

Chengping Zhang, KLA-Tencor Corporation (USA)

Session Chairs

13 3D and Machine Vision Methods

Peisen S. Huang, Stony Brook University (USA)

2 3D Methods and Data Merging

Qingying Hu, GE Global Research Center (USA)

3 3D Applications

Kevin G. Harding, GE Global Research Center (USA)

$4 \quad$ System Optimization Methods

Toru Yoshizawa, Saitama Medical University (Japan) 
Downloaded From: https://www.spiedigitallibrary.org/conference-proceedings-of-spie on 26 Apr 2023

Terms of Use: https://www.spiedigitallibrary.org/terms-of-use 